\title{
Study on International Construction of University Teaching Staff
}

\author{
Y. Yuan, B. Zhao, X.W. Huang, M.H. Jiang, Y.G. Mu \\ Harbin Institute of Technology, Harbin, P.R. China
}

\begin{abstract}
The internationalization of teaching staff is the core of internationalization of university and the precondition to develop international students. It is also a necessity to raise the academic level of universities and to promote the overall development of China's social economy. However, there are some problems in the international construction of university teaching staff, such as the lack of deep understanding and perfect system of internationalization of university teaching staff and the low internalization level of the teaching staff's educational background and so on. Universities should develop a good international development idea and set up international concepts of management and talents, so as to establish a teaching staff management system in accordance with international standards. Through strengthening training to improve the teaching staff's ability to use foreign languages, the internationalization of higher education can be implemented successfully and the goal of internationalization can be achieved.
\end{abstract}

KEYWORD: universities; teaching staff; internationalization

\section{INTRODUCTION}

With the rapid development of global economic integration, the internationalization of higher education has been an irresistible trend in the development of world education. Teachers being the subjects of university personnel training, disciplinary development, academic level and prestige of schools, their internationalization level play an core role in the international development of universities. The internationalization of teaching staff is the common feature of world-class universities and also the fundamental guarantee for China to establishing world-class universities. A Long-term Plan on Education Reform and Development indicates clearly that "through learning from the international advanced educational concept and experience, it is favorable to promote education reform and development and to raise the international position, influence and competitiveness of our education. We should meet the requirements of the social economy opening, so as to train a large number of international talents with international perspectives who have a good knowledge of international rules and are able to participate in international affairs and international competition." It points the way for the international development of universities.
2 THE SIGNIFICANCE OF INTERNATIONALIZATION OF UNIVERSITY TEACHING STAFF

\subsection{The internationalization of teaching staff is the core of internationalization of university.}

As the special educational institutions to cultivate high-ranking talents, universities are an important index to evaluate the comprehensive national powers. The internationalization of universities is of great significance in the long-term development of a country's education, economy even politics. It is an essential and important means to connect with the outside world. Besides, it also plays a significant role in promoting a country's comprehensive national power and international competitiveness. Imparting knowledge and educating people in schools, teachers are the core resources for universities to train talents and also the spirit of universities. Only teachers with international perspectives and international levels have the ability to carry out world-class teaching, scientific research and discipline building, to train first-class talents and to be recognized by the world. 


\subsection{The internationalization of teaching staff is the precondition to develop international students.}

The international structure of student resources is not only the important measure for world-class universities to improve the quality of student resources but also one of the symbols of world-class universities. Without international student resources, it is impossible to establish world-class universities. In order to attract students from all over the world, the first requirement for the universities is to be equipped with teachers from all over the world. A university with world famous teachers can not only attract foreign elites and train outstanding talents with international competitiveness, but also establish the reputation of a university that can make the university enduring. The history of higher education development proves that the higher the level of teaching staff internationalization is and the more diversified the discipline backgrounds are, the more students it will attract and the deeper mutual understanding the teachers and students will have. As a result, it will be more conducive for teachers and students to discuss profound knowledge freely.

\subsection{The internationalization of teaching staff is a necessity to raise the academic level of universities.}

Supported by student training and scientific research, universities shoulder the tasks of scientific research and academic innovation. Therefore, the academic level directly influences the ability of training students and the comprehensive strength of a university. Under the pattern of globalization, universities of any country cannot ignore the international communication and integration of scientific research to work behind closed doors. In the internationalization trend of academic researches, the academic researchers in universities have been integrated into the development framework of worldwide academy. As a result, the academic vision is expanded unprecedentedly; academic resources are greatly enriched; academic competitiveness is increasingly fierce. Therefore, in order to gain the academic discourse power in the world, it is a must to integrate into the international academic languages and to follow the international academic evaluation system and evaluation index.

\subsection{The internationalization of teaching staff is a necessity to promote the overall development of China's social economy.}

The internationalization of university teaching staff will strongly promote the thought innovation and transformation in economic society, the learning from advanced experience and the spreading of the advanced culture, so as to advance the comprehensive development of Chinese economy and society. In the process of international construction of university teaching staff, the training of teachers' international thinking patterns and innovation consciousness conforms with the objective requirements of economic and social development; international communications between teachers can create favorable conditions to learn foreign advanced ideas, innovation consciousness, scientific thought and managerial experience; and the expansion of international perspectives and the international abilities of teachers can update social perceptions as a whole and enhance the quality of the Chinese people. The international construction of university teaching staff can provide a directional guidance, a demonstration model and methodology for talent cultivation and staff training in various industries and sectors.

\section{THE PROBLEMS IN THE INTERNATIONAL CONSTRUCTION OF UNIVERSITY TEACHING STAFF}

\subsection{The understanding of international construction of teaching staff should be further deepened.}

Talent team is an important part in teaching staff and talents play a leading role in the internationalization of higher education. The international university teaching staff not only should have extensive knowledge and superb professional skills, but also should have modern educational consciousness and international educational concepts and learn about the international advanced teaching and the new thoughts and ideas of scientific research. According to the current situations, when some universities take part in the international competitions, they pay much attention to the improvement of conditions for running schools, the expansions of school size and the increase of enrollment. But they are lack of understanding of the international construction of teaching staff. Strengthening the international construction of teaching staff has a favorable effect on many aspects, such as the transformation of educational concept, the forming of international educational principles, the quality and ability of teachers, the international competitiveness of universities, the teachers' perspectives and international communication channels and the further integration of international culture, the up-todate connotative development of universities and keeping eternal vitality. People need to have a better and further understanding about the international construction of university teaching staff.

\subsection{The system of internationalization of university staff should be further perfected.}

National education authorities established some directional regulations in general way for the 
construction of university teaching staff and offered motivation in the way of assessment and review. As a result, it effectively promoted the construction of university teaching staff. But many universities are lack of the related system of international construction of teaching staff. In some universities, the international constructions of teaching staff are lack of specification standards, goal constraint and the corresponding evaluation and motivation. As a result, some universities have vague goal and less confidence in international construction of teaching staff. And many measures are just forms with little effect. In some universities, the international construction of teaching staff is based on domestic development, aiming at maintaining the current situations of existing major and discipline teaching. They are lack of confidence and motivation to compete internationally. It is difficult for overseas talents brought to universities to adapt to the multiple assessment standards of teaching, scientific research and social service in domestic universities. That is to say the "localization" is slow. In domestic universities, the security mechanisms of nationalities, pensions and medical insurance for foreign talents are not compatible with international standards.

\subsection{The internalization of the teaching staff's} educational background has a low level.

Apart from few high-level universities in China, teachers in many universities are lack of systematic international education experience. Some teachers have international communication experience, but they are lack of systematic specialized leaning and the training of perspectives. The portion of teachers with more than one-year international experience is small and the portion of teachers with doctor's degrees of foreign universities is smaller. Teachers in domestic universities don't have a deep international study on expertise. And they don't have systematic and prospective leaning about the development of the foreign relevant field of expertise. Some university teachers don't have the foreign language level required by overseas studying due to self-inability. Therefore, there are difficulties for them to apply to study abroad, which is one of the important factors restricting the international construction of university teaching staff.

\section{THE APPROACH TO IMPROVE INTERNATIONALIZATION OF TEACHING STAFF}

\subsection{A good international development thought should be developed.}

Several decades ago, many advanced capitalist countries have changed ideas of universities and teachers by establishing regulations to improve the internalization of teaching staff. International Education Law and relevant laws and regulations have not yet been passed in our country, but universities should abandon the backward ideas, promote the concept of internationalization of school-running and contribute to the internationalization of teaching staff. Universities should adopt internationalized development strategy, making relevant regulations on the development of internationalized teaching staff and the introduction of talents with internationalized background and allocating special funds. The implementation of these regulations should also be ensured. Under the overall strategies of universities, different departments should work out concrete methods according with its own development, and join forces with universities. Through convening international strategy seminars and establishing international strategy committee, universities could also implement the results achieved by international strategy seminar and help the proceeding of various works from an international perspective.

International concepts of management and talents should be set up. With the growing trends of internationalization of higher education, the traditional executive leadership and empirical school-running mode can no longer adapt to the development goals and thoughts of higher education in the future. Therefore, from administrative department of higher education to executive department of universities, to every teacher and staff, they all should broaden their views and have a fully understanding of the development trends of international higher education before look at the development situation, direction and mode of higher education in our country so that they can formulate university development strategy, instruct individual teaching, scientific research and management work. Universities should set talent training standard, content and mechanism from international perspective, and cultivate talents with capacity to fit into the international environment. At the same time, it should be noticed that internationalization increases the mobility of talents, so internationalization of talents could only be achieved in a more mobile talent environment. Enhancing mobility as well as preventing the loss of talents is very important.

\subsection{A teaching staff management system in accordance with international standards should be established.}

The rationality of teaching staff management system is related to the reasonable allocation of teacher resources, the improvement of teachers' working enthusiasm and the development of teachers' potential to the maximum. For government, 
educational institutions and authorities should actively enact and issue relevant laws and regulations: formulate an operating mechanism about international development of university teaching staff focusing on updating teachers' concept, optimizing teaching staff and promoting teachers' international consciousness regarding international development as guiding concept, combining the current international development situation of teaching staff with their own characteristics and referring to the advanced experience from abroad. For universities, based on their own characteristics, they should formulate the corresponding supervision operating mechanism with the goal of substantial progress according to operating mechanism established by the state so that laws and regulations promulgated by the state could be more tender and deepening and its operability and controllability could be improved, for example, abolishing teacher tenure and adopting employment to improve teachers' learning enthusiasm; changing the converging evaluation method and employing different performance assessment according characteristics of different positions and disciplines to optimize teaching staff.

\subsection{The teaching staff's ability to use foreign languages should be improved through strengthening training.}

Language is the carrier of thoughts and culture, so teachers can achieve the communication and deep exchanges of two sides, enter international academic frontier, optimize professional knowledge structure, absorb advanced education concept and strengthen the ability of international academic exchanges only when languages of teachers are interlinked. And universities could offer bilingual courses or total foreign language courses to absorb and receive overseas students and conduct various kinds of cooperation with universities abroad only when teachers have mastered foreign languages. Therefore, language for international communication, especially English is important to realize the internationalization of teaching staff and universities. Intensive training class in universities, sending teachers to domestic foreign language universities for English training, sending teachers to famous international universities for learning and training of teachers on listening, speaking, reading and writing is the precondition of improve the internationalization of teaching staff.

\section{CONCLUSION}

The internationalization of teaching staff is the core of the internationalization of universities, and is the basis to achieve the international atmosphere of campus, the precondition to achieve international academic research, the mediation for international education and the bridge for international students. The improvement of internationalization of teaching staff requires unified planning of universities, balance between teaching and scientific research, cooperation between different departments, broadening of internationalization development path of teaching staff, creation of international atmosphere and formulation of relevant incentive policy to guide teachers improve internationalization independently. The internationalization of teaching staff is the guarantee to implement and realize the internationalization of higher education.

\section{REFERENCES}

[1] Z.J, Hong. Study on actuality and innovation of internationalization of University Teaching Staff. Journal of Yangtze university: 2014(4):142-144.

[2] L.S, L. Promote the teachers troop internationalization, Deepen the reform of higher education. Chinese higher education: 2014(11):19-22. 